NASA/TM-2005-214032

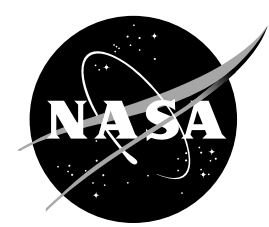

\title{
Hydrogen-Oxygen PEM Regenerative Fuel Cell Development at the NASA Glenn Research Center
}

David J. Bents and Vincent J. Scullin

Glenn Research Center, Cleveland, Ohio

Bei-Jiann Chang, Donald W. Johnson, and Christopher P. Garcia QSS Group, Inc., Cleveland, Ohio

Ian J. Jakupca

Analex Corporation, Brook Park, Ohio 
Since its founding, NASA has been dedicated to the advancement of aeronautics and space science. The NASA Scientific and Technical Information (STI) Program Office plays a key part in helping NASA maintain this important role.

The NASA STI Program Office is operated by Langley Research Center, the Lead Center for NASA's scientific and technical information. The NASA STI Program Office provides access to the NASA STI Database, the largest collection of aeronautical and space science STI in the world. The Program Office is also NASA's institutional mechanism for disseminating the results of its research and development activities. These results are published by NASA in the NASA STI Report Series, which includes the following report types:

- $\quad$ TECHNICAL PUBLICATION. Reports of completed research or a major significant phase of research that present the results of NASA programs and include extensive data or theoretical analysis. Includes compilations of significant scientific and technical data and information deemed to be of continuing reference value. NASA's counterpart of peerreviewed formal professional papers but has less stringent limitations on manuscript length and extent of graphic presentations.

- TECHNICAL MEMORANDUM. Scientific and technical findings that are preliminary or of specialized interest, e.g., quick release reports, working papers, and bibliographies that contain minimal annotation. Does not contain extensive analysis.

- CONTRACTOR REPORT. Scientific and technical findings by NASA-sponsored contractors and grantees.
- CONFERENCE PUBLICATION. Collected papers from scientific and technical conferences, symposia, seminars, or other meetings sponsored or cosponsored by NASA.

- SPECIAL PUBLICATION. Scientific, technical, or historical information from NASA programs, projects, and missions, often concerned with subjects having substantial public interest.

- TECHNICAL TRANSLATION. Englishlanguage translations of foreign scientific and technical material pertinent to NASA's mission.

Specialized services that complement the STI Program Office's diverse offerings include creating custom thesauri, building customized databases, organizing and publishing research results ... even providing videos.

For more information about the NASA STI Program Office, see the following:

- Access the NASA STI Program Home Page at http://www.sti.nasa.gov

- E-mail your question via the Internet to help@sti.nasa.gov

- Fax your question to the NASA Access Help Desk at 301-621-0134

- Telephone the NASA Access Help Desk at 301-621-0390

- Write to:

NASA Access Help Desk

NASA Center for AeroSpace Information 7121 Standard Drive

Hanover, MD 21076 
NASA/TM-2005-214032

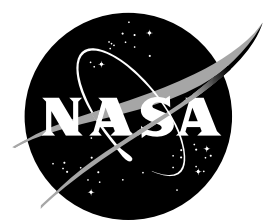

\section{Hydrogen-Oxygen PEM Regenerative Fuel Cell Development at the NASA Glenn Research Center}

David J. Bents and Vincent J. Scullin

Glenn Research Center, Cleveland, Ohio

Bei-Jiann Chang, Donald W. Johnson, and Christopher P. Garcia QSS Group, Inc., Cleveland, Ohio

Ian J. Jakupca

Analex Corporation, Brook Park, Ohio

Prepared for the

2005 Fuel Cell Seminar

cosponsored by Ansaldo Fuel Cells, Ballard Power Systems, Inc., Ohio Means Business, Hydrogen and Fuel Cell Letter, Acta, Engelhard Corporation, Entegris, Inc., W.L. Gore and Associates, Inc., Umicore Autocat USA, Inc., Nextech Materials, Columbian Chemicals Company, Sud-Chemie, Tanaka Precious Metals Group, Siemens, Poly Fuel, and U.S. Fuel Cell Council

Palm Springs, California, November 14-18, 2005

National Aeronautics and

Space Administration

Glenn Research Center 
This work was sponsored by the Low Emissions Alternative Power Project of the Vehicle Systems Program at the NASA Glenn Research Center.

Available from

NASA Center for Aerospace Information 7121 Standard Drive

Hanover, MD 21076
National Technical Information Service 5285 Port Royal Road Springfield, VA 22100

Available electronically at http:/ /gltrs.grc.nasa.gov 


\title{
Hydrogen-Oxygen PEM Regenerative Fuel Cell Development at the NASA Glenn Research Center
}

\author{
David J. Bents and Vincent J. Scullin \\ National Aeronautics and Space Administration \\ Glenn Research Center \\ Cleveland, Ohio 44135 \\ Bei-Jiann Chang, Donald W. Johnson, and Christopher P. Garcia \\ QSS Group, Inc. \\ Cleveland, Ohio 44135 \\ Ian J. Jakupca \\ Analex Corporation \\ Brook Park, Ohio 44142
}

\begin{abstract}
The closed-cycle hydrogen-oxygen PEM regenerative fuel cell (RFC) at the NASA Glenn Research Center (NASA Glenn) has successfully demonstrated closed cycle operation at rated power for multiple charge-discharge cycles. During charge cycle the RFC has absorbed input electrical power simulating a solar day cycle ranging from zero to $15 \mathrm{kWe}$ peak, and delivered steady $5 \mathrm{kWe}$ output power for periods exceeding $8 \mathrm{hr}$. Orderly transitions from charge to discharge mode, and return to charging after full discharge, have been accomplished without incident. Continuing test operations focus on:

(1) Increasing the number of contiguous uninterrupted charge discharge cycles

(2) Increasing the performance envelope boundaries

(3) Operating the RFC as an energy storage device on a regular basis

(4) Gaining operational experience leading to development of fully automated operation

(5) Developing instrumentation and in situ fluid sampling strategies to monitor health and anticipate breakdowns
\end{abstract}

\section{Introduction}

The RFC is beginning to demonstrate its potential as an energy storage device for aerospace solar power systems such as solar electric aircraft, lunar and planetary surface installations; any airless environment where minimum system weight is critical.

The closed-cycle hydrogen-oxygen PEM regenerative fuel cell (RFC) at the NASA Glenn Research Center (Refs. 1 and 2) has successfully demonstrated closed cycle operation at rated power for multiple charge-discharge cycles. During charge cycles the RFC absorbed input electrical power simulating a solar day cycle ranging from zero to $15 \mathrm{kWe}$ peak. During discharge cycles it delivered steady 4.5 to $4.8 \mathrm{kWe}$ output power for periods exceeding $8 \mathrm{hr}$. Orderly transitions from charge to discharge mode, and return to charging after full discharge, were accomplished without incident. Continuing test operations focus on:

(1) Increasing the number of contiguous uninterrupted charge discharge cycles

(2) Increasing the performance envelope boundaries

(3) Operating the RFC as an energy storage device on a regular basis 
(4) Gaining operational experience leading to development of fully automated operation

(5) Developing instrumentation and in situ fluid sampling strategies to monitor health and anticipate breakdowns

Table 1 presents a summary of test experience from August 2004 (date of last Fuel Cell Seminar publication) to the end of July 2005. In this table, "Power Absorbed" is the range of power levels sustained by the electrolyser in charging mode, and "Power Delivered" is the range of output powers delivered by the fuel cell stack and ancillaries during discharge mode. In the charge/discharge cycle tests, the electrolyser was normally driven by a power profile that approximates electrical output of a flat plate solar collector (hence the zero to $15 \mathrm{kWe}$ peak), while the fuel cell was operated to deliver the maximum output power that could be sustained. The "longest elapsed run time" is defined as the longest elapsed time period during these tests that the RFC operated as an energy storage system uninterrupted for any reason other than orderly startup, shutdown or transitions between modes. For example, the test run of March 9-29, 2005, shown in Figure 1, reports a longest elapsed run time of $70 \mathrm{hr}$. This run contained two complete charge/discharge cycles which were carried out over a two week period, where electrolysis was accomplished in segments using a $4.5 \mathrm{kWe}$ short stack. The segments were not contiguous but interrupted by normal (end of working day) shutdowns. The system however, was capable of resuming operation at any time during the shutdown period, hence the accumulation of elapsed hours from one segment to the next (elapsed hour accumulations ended when a test segment got curtailed).

TABLE 1.-NASA CLOSED CYCLE RFC TESTING SUMMARY AUGUST 2004 TO JULY 2005

\begin{tabular}{|c|c|c|c|c|c|}
\hline Date(s) of Test & $\begin{array}{l}\text { Test } \\
\text { Objectives }\end{array}$ & $\begin{array}{l}\text { Power } \\
\text { absorbed }\end{array}$ & $\begin{array}{l}\text { Power } \\
\text { delivered }\end{array}$ & $\begin{array}{l}\text { Longest } \\
\text { elapsed } \\
\text { run }\end{array}$ & $\begin{array}{l}\text { Test Curtailed } \\
\text { By: }\end{array}$ \\
\hline Aug 3 - 4, 2004 & $\begin{array}{l}\text { Charge/Discharge } \\
\text { cycles }+ \text { transitions }\end{array}$ & $\begin{array}{l}2.1-11 \\
\mathrm{kWe}\end{array}$ & $\begin{array}{l}4.5-4.8 \\
\mathrm{kWe}\end{array}$ & $21 \mathrm{hr}$ & $\begin{array}{l}\text { Pressure spike causes EZ } \\
\text { stack failure }\end{array}$ \\
\hline $\begin{array}{l}\text { Oct } 22-25 \\
2004\end{array}$ & $\begin{array}{l}\text { Non-venting Cell } \\
\text { flooding prevention }\end{array}$ & $\begin{array}{l}\text { (EZ stack } \\
\text { not used) }\end{array}$ & $\begin{array}{l}3.0-4.5 \\
\mathrm{kWe}\end{array}$ & $2.5 \mathrm{hr}$ & $\begin{array}{l}\text { Cell flooding, vent/purge } \\
\text { req'd }\end{array}$ \\
\hline $\begin{array}{l}\text { Nov } 30 \text { - Dec 1, } \\
2004\end{array}$ & $\begin{array}{l}\text { New EZ short stack } \\
\text { performance tests }\end{array}$ & $\begin{array}{l}\text { zero to } \\
6 \mathrm{kWe}\end{array}$ & $\begin{array}{l}\text { (FC stack } \\
\text { not used) }\end{array}$ & $10 \mathrm{hr}$ & Successful outcome \\
\hline $\begin{array}{l}\text { Dec } 8 \text { - 10, } \\
2004\end{array}$ & $\begin{array}{l}\text { Charge/Discharge } \\
\text { cycles, new EZ stack }\end{array}$ & $\begin{array}{l}\text { zero to } \\
15 \mathrm{kWe}\end{array}$ & $\begin{array}{l}4.5-4.8 \\
\mathrm{kWe}\end{array}$ & $9 \mathrm{hr}$ & FC stack crossover \\
\hline $\begin{array}{l}\text { Dec } 16-17, \\
2004\end{array}$ & $\begin{array}{l}\text { Multiple Chge/Dischge } \\
\text { cycles + transitions }\end{array}$ & $\begin{array}{l}\text { zero to } \\
15 \mathrm{kWe}\end{array}$ & $\begin{array}{l}\text { (FC stack } \\
\text { not used) }\end{array}$ & $10 \mathrm{hr}$ & $\begin{array}{l}\text { Computer SW platform } \\
\text { failure }\end{array}$ \\
\hline $\begin{array}{l}\text { Feb } 14 \text { - } \\
\text { Mar18, } 2005\end{array}$ & $\begin{array}{l}\text { Safety Improvements } \\
\text { new software checkout }\end{array}$ & $\begin{array}{l}3.2-4.5 \\
\mathrm{kWe}\end{array}$ & $\begin{array}{l}2.5- \\
4.5 \mathrm{kWe}\end{array}$ & $8 \mathrm{hr}$ & Successful Outcome \\
\hline $\begin{array}{l}\text { Mar } 9 \text { - 29, } \\
2005\end{array}$ & $\begin{array}{l}\text { Charge/Discharge } \\
\text { cycles }+ \text { transitions }\end{array}$ & $4.5 \mathrm{kWe}$ & $4.8 \mathrm{kWe}$ & $70 \mathrm{hr}$ & Recirculation pump failures \\
\hline May 2 - 5, 2005 & $\begin{array}{l}\text { Multiple Chge/Dischge } \\
\text { cycles + transitions }\end{array}$ & $6 \mathrm{kWe}$ & $3.2 \mathrm{kWe}$ & $4 \mathrm{hr}$ & EZ stack failure (bad cell) \\
\hline $\begin{array}{l}\text { May 17-20, } \\
2005\end{array}$ & $\begin{array}{l}\text { Multiple Chge/Dischge } \\
\text { cycles + transitions }\end{array}$ & $\begin{array}{l}\text { zero to } \\
15 \mathrm{kWe}\end{array}$ & $4.5 \mathrm{kWe}$ & $7 \mathrm{hr}$ & FC stack cell flooding \\
\hline $\begin{array}{l}\text { June } 21 \text { - July } \\
1,2005\end{array}$ & $\begin{array}{l}\text { Multiple Chge/Dischge } \\
\text { cycles + transitions }\end{array}$ & $\begin{array}{l}\text { zero to } \\
15 \mathrm{kWe}\end{array}$ & $\begin{array}{l}4.5-4.8 \\
\mathrm{kWe}\end{array}$ & $149 \mathrm{hr}$ & Successful outcome \\
\hline
\end{tabular}




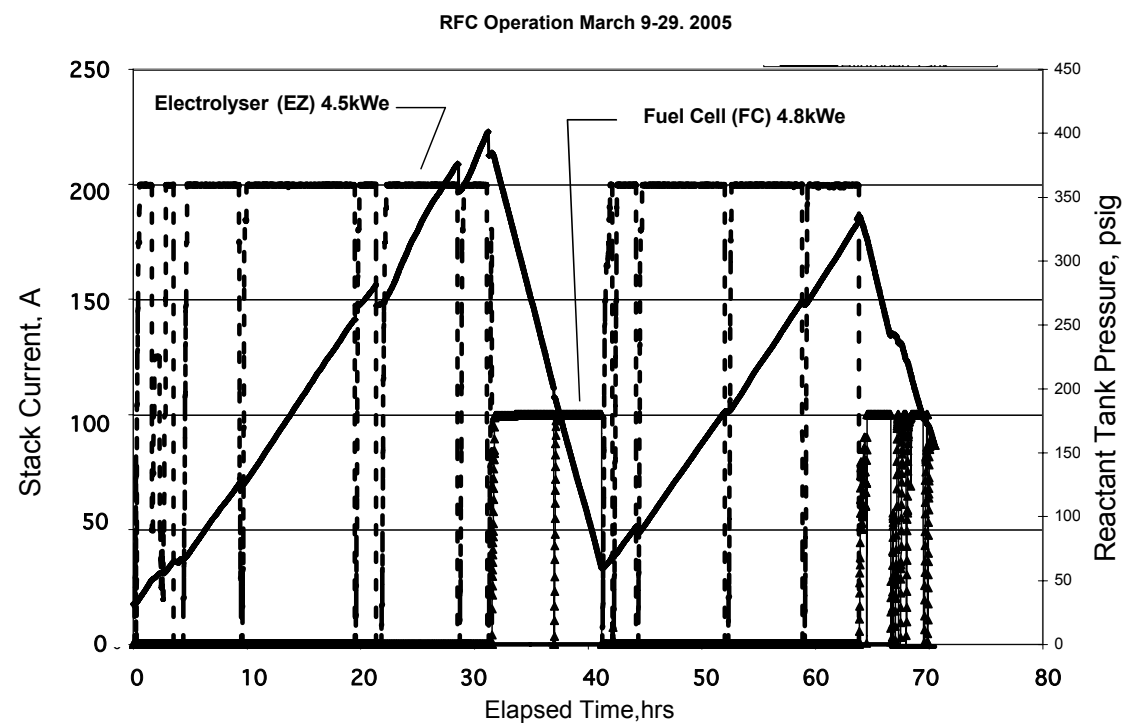

Figure 1.-NASA closed cycle RFC testing March 9-29, 2005.

Although the majority of the tests logged in Table 1 were curtailed by failures, the failures spawned hardware and software improvements which eventually rendered the system capable of longer operations at rated power. These improvements included: (1) methods to isolate and remove inert contaminants from the stack, thereby reducing to zero the amount of venting/purging that is required; (2) balanced void volumes within the recirculation loops, and carefully timed valves and orifices to minimize differential pressure swings due to mode transitions and reactant recombination; (3) "Fuzzy Logic" automated control for rapid power transitions while maintaining equilibrium within the fuel cell stack and recirculation loops (faster ramp up than a human operator); and (4) control strategies to identify and respond to individual cell dropoffs in an appropriate and timely manner (i.e., distinguish between flooding, dryout or inert contamination) leading to development of fully automatic controls.

A significant development milestone was achieved during the test series June 24 to July 1 when the RFC was operated for seven complete charge/discharge cycles without failure. Five of these cycles were run continuously over an uninterrupted $120 \mathrm{hr}$ period, from June 26 to July 1 . These five contiguous back-to-back charge/discharge cycles at full power, with transitions, are shown in Figure 2.

During charge cycles the RFC absorbed daytime solar electrical current profiles of 0 to $15 \mathrm{kWe}$ storing the energy as pressurized hydrogen and oxygen gas. The RFC delivered back the stored energy during discharge as steady 4.5 to $5 \mathrm{kWe}$ electrical power. Electrical energy delivered during each cycle ranged from 38 to $40 \mathrm{~kW} / \mathrm{hr}$. Full power was sustained during both charge and discharge modes throughout the duration of test demonstrating maximum system performance. Smooth transitions at the end of the electrolysis (charge) cycle to fuel cell (discharge) mode were repeatedly accomplished, and smooth transitions at the end of discharge (fuel cell) mode back to charge mode (electrolysis) were repeated. At the conclusion of testing the hardware remained fully capable of repeating another charge/discharge cycle without servicing or intervention. The RFC demonstrated fully closed cycle operation during the test period (hermetically sealed system, nothing goes in, nothing goes out other than electrical power and heat). Reactant inventory (water) losses measured at the end of the test period (seven full charge/discharge cycles including the five contiguous back-to-back cycles) were less than 1 percent. 


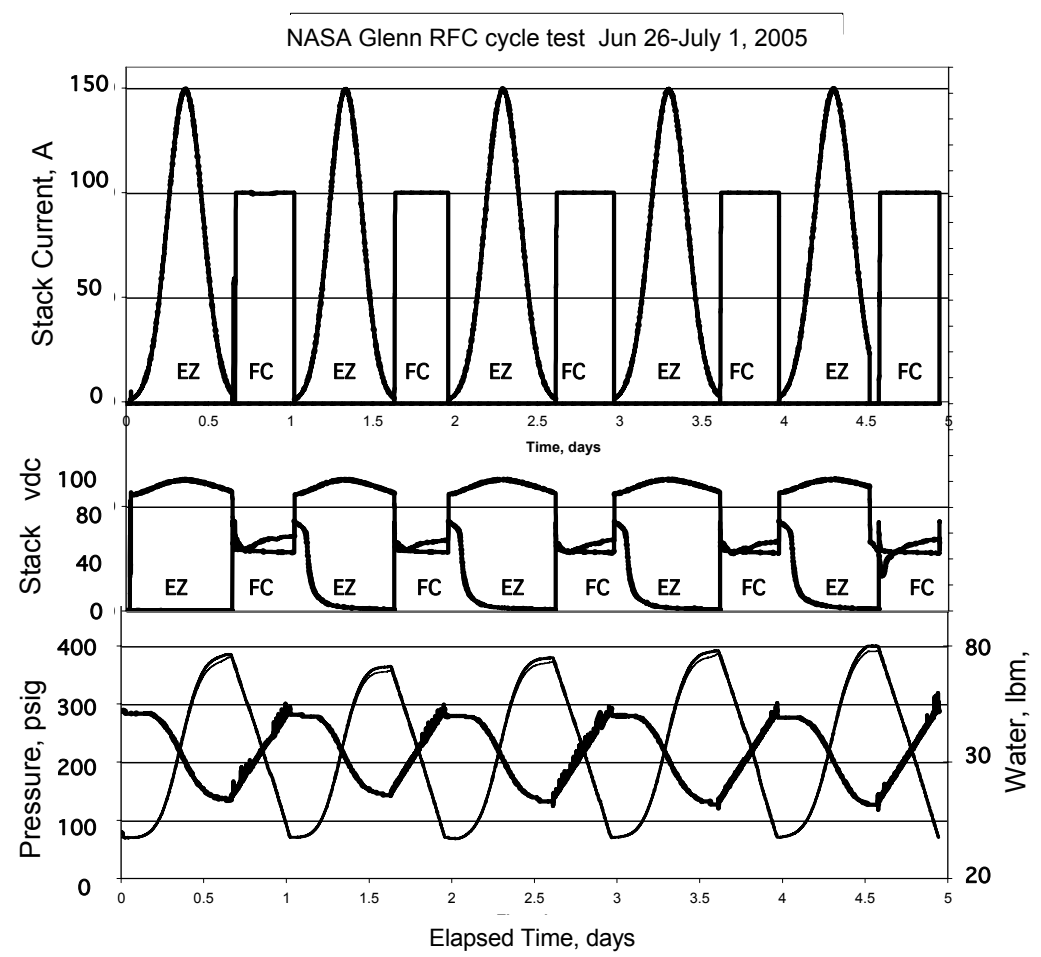

Figure 2.-NASA closed cycle RFC testing June 26 to July 1, 2005.

Figure 2 summarizes system performance over the five days operation. In the topmost plot "Stack Current," the $\sin ^{2}$-shaped trace represents electrolyser current applied during charge (day) cycle, which is followed by a square wave shaped trace that represents fuel cell output current during the discharge (night) cycle, plotted over the entire five day period. The day/night cycle applied was 16/8 hr, respectively, roughly corresponding to local summertime day/night conditions. In the middle plot, the top trace is electrolyser stack voltage, while the lower trace is the fuel cell stack voltage. Note how stack voltages idle to open circuit then fall during recombination. The RFC system ran completely sealed closed cycle over the five day period (no venting no purging). The bottom plot depicts overall reactant balance over the five days, coincident with the power profiles. The wide amplitude traces correspond to (oxygen and hydrogen) reactant tank pressures, while the smaller amplitude trace corresponds to pounds of water remaining, as measured by the oxygen phase separator tank level. Water inventory is minimum when reactant tank pressures are at their peak. As hydrogen and oxygen are consumed the water level rises. Note how water level at the end of the five days is just about the same as it was in the beginning. Since the fuel cell stack was operating at maximum current during these tests, overall system round trip energy storage efficiency was less than 50 percent. This demonstration fulfilled NASA's Low Emissions Alternative Power Aircraft Fuel Cell Power System Regenerative Fuel Cell (LEAP AFCPS RFC) Task FY05 milestone criteria "Demonstrate repeatable system performance over multiple (4 to 10) repeated contiguous charge/discharge cycles" thus confirming the RFC's potential as an energy storage device for aerospace solar power systems such as solar electric aircraft, lunar and planetary surface installations; any airless environment where minimum system weight is critical. 


\section{References}

1. D.J. Bents, V.J. Scullin, B.J. Chang, D.W. Johnson, and C.P. Garcia, "Hydrogen-Oxygen PEM Regenerative Fuel Cell Energy Storage System," 2004 Fuel Cell Seminar, San Antonio, TX, Nov. 1-5, 2004, NASA/TM-2005213381.

2. B.J. Chang, D.W. Johnson, C.P. Garcia, I.J. Jakupca, V.J. Scullin, and D.J. Bents, "Regenerative Fuel Cell Test Rig at Glenn Research Center," Proc. First International Energy Conversion Engineering Conference (AIAA, ASME, IEEE), Portsmouth, VA, Aug. 17-21, 2003, AIAA-2003-5942, NASA/TM-2003-212375. 


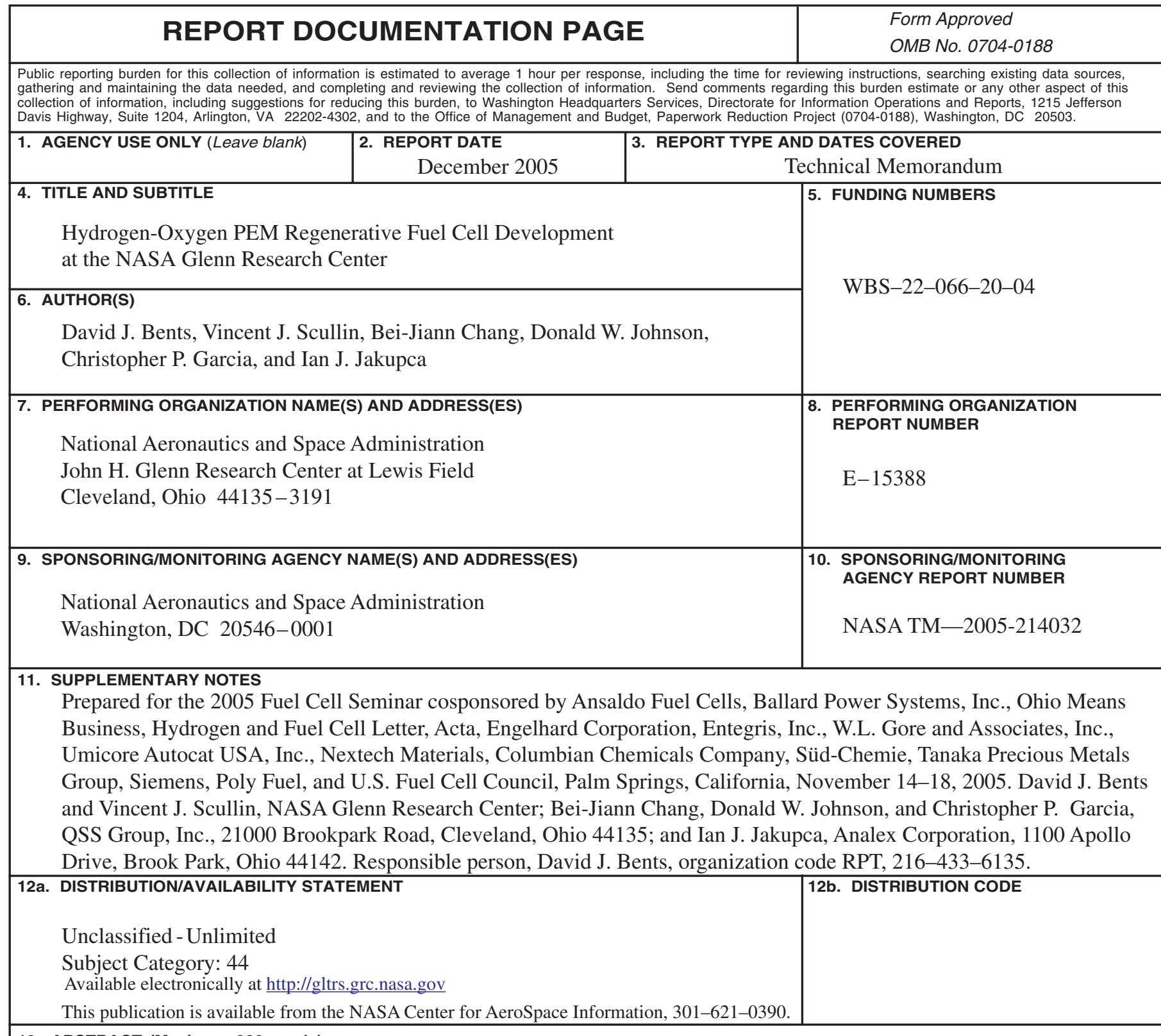

13. ABSTRACT (Maximum 200 words)

The closed-cycle hydrogen-oxygen PEM regenerative fuel cell (RFC) at the NASA Glenn Research Center has successfully demonstrated closed cycle operation at rated power for multiple charge-discharge cycles. During charge cycle the RFC has absorbed input electrical power simulating a solar day cycle ranging from zero to $15 \mathrm{kWe}$ peak, and delivered steady $5 \mathrm{kWe}$ output power for periods exceeding $8 \mathrm{hr}$. Orderly transitions from charge to discharge mode, and return to charging after full discharge, have been accomplished without incident. Continuing test operations focus on: (1) Increasing the number of contiguous uninterrupted charge discharge cycles; (2) Increasing the performance envelope boundaries; (3) Operating the RFC as an energy storage device on a regular basis; (4) Gaining operational experience leading to development of fully automated operation; and (5) Developing instrumentation and in situ fluid sampling strategies to monitor health and anticipate breakdowns.

14. SUBJECT TERMS

Fuel cells; Regenerative fuel cells; Hydrogen/oxygen

\begin{tabular}{|c|c|}
\hline $\begin{array}{c}\text { 17. SECURITY CLASSIFICATION } \\
\text { OF REPORT } \\
\text { Unclassified }\end{array}$ & $\begin{array}{c}\text { 18. SECURITY CLASSIFICATION } \\
\text { OF THIS PAGE } \\
\text { Unclassified }\end{array}$ \\
\hline
\end{tabular}

19. SECURITY CLASSIFICATION OF ABSTRACT

Unclassified

\section{NUMBER OF PAGES}

11

16. PRICE CODE

20. LIMITATION OF ABSTRACT 

